F 52 - National Security

\title{
POLAND'S ENERGY SECURITY IN THE PROCESS OF ENERGY TRANSFORMATION
}

\section{Koczan M.}

doctor of political studies, Institute of International Studies,University of Wroclaw, Poland, marcin.koczan@uwr.edu.pl

\begin{abstract}
The issue of energy security has been present in the literature for several decades. Scientific studies focus mainly on the theoretical aspect of this concept. Many of them also describe and analyse the practical dimension of energy security, such as: international trade in raw materials, safety of transport of raw materials, energy production and transmission systems. For over a dozen years, the awareness of climate change, its causes and effects has been growing. Countries and international organizations are taking action to reduce greenhouse gases. The European Union is one of the world leaders in this process. Poland as a member state is obliged to implement the adopted energy and climate commitments. The electro-energy sector in Poland is based on the combustion of fossil fuels. Reducing a high share of coal in the energy mix is a long and very costly process. The speed and efficiency of this transformation affects the level of energy security in Poland.
\end{abstract}

Keywords: Energy security, energy transformation, Poland, coal, natural gas

\section{Introduction:}

One of the most important factors influencing Poland's energy security is the EU climate and energy policy. The European Union, regardless of the political profile of its main bodies (European Parliament, European Commission, European Council), strives to achieve ambitious goals of reducing $\mathrm{CO}_{2}$ emissions and increasing the share of renewable energy sources in final consumption. The determination of the EU institutions and some member states to implement the Green Deal suggests that the efforts of the Polish side to slow down this process will not bring the expected results.

Increasingly ambitious targets for reducing $\mathrm{CO}_{2}$ emissions will have a negative impact on the price of electricity generated from coal sources. The Polish power system is based on coal-fired power plants. Out of the total number of 90 units included in centrally dispatched generating units (CDGUs), as many as 70 exceeded the assumed operation time [Bronk L., Czarnecki B.,. Magulski $R$ 2019]. They should be modernized, adapted to the BAT directive (Best Available Techniques) in order to improve their flexibility, so that they can complement and support RES (Renewable Energy Sources).

There is a clear trend of abandoning large-scale energy, especially based on conventional sources, in favour of smaller sources located close to consumers. In this context, the need to build a nuclear power plant in Poland should be re-examined.

\section{Purpose of the study:}

The aim of the article is to describe the direction of Poland's energy transformation and to diagnose the main threats and challenges.

\section{Main research results:}

\section{Energy security - the scope of the concept}

The term "energy security" has been defined in the most important government documents relating to the broadly understood energy sector. For example, in the Energy Law of April 10, 1997, it was defined as the state of the economy that enables the coverage of the current and future customer demand for fuels and energy in a technically and economically justified manner, while 
maintaining environmental protection requirements (The Act of April 10, 1997, Energy Law, art. 3 point 16). In turn, the document Energy Policy of Poland until 2030 states that the security of fuel and energy supplies is understood as ensuring a stable supply of fuels and energy at a level that guarantees satisfying domestic needs and at prices accepted by the economy and society, assuming the optimal use of domestic resources of raw materials. Energy and by diversifying the sources and directions of supplies of crude oil, liquid and gas fuels [Poland's Energy Policy until 2030].

According to the definition contained in the draft document Poland's Energy Policy until 2040 (hereinafter PEP2040), energy security means the current and future satisfaction of the needs of customers for fuels and energy in a technically and economically justified manner, while maintaining environmental protection requirements. This means the present and future guarantee of the security of supply of raw materials, production, transmission and distribution, i.e. the complete energy chain [Poland's Energy Policy until 2040].

The above definitions basically focus on three main aspects:

A) Continuous / uninterrupted fuel and energy supply;

B) Meeting the demand (current and future) for energy;

C) The prices for supplied energy should be acceptable for the economy and society.

Taking into account the above, the main threats to energy security understood in this way can be defined:

Ad 1 The power supply may be interrupted due to natural causes (natural disasters, fires, strong winds, floods, snowfall, extreme temperatures, low water levels, etc.) or technical failures. Despite advanced prognostic tools, these phenomena are largely unpredictable. However, their effects can be minimized by introducing early warning systems, duplicating certain systems, maintaining the critical infrastructure at a sufficiently high level and efficient crisis management. If in this way it is not possible to prevent interruptions in energy supplies, at least the time of interruptions in supplies can be reduced to a minimum.

Ad 2 Adapting supply to demand actually boils down to the ability to predict changes in energy demand in relation to such phenomena as: increase / decrease in the number of recipients, development / degradation of industry, especially in relatively energy-intensive industries, change in the life model of the population, increase / decrease in energy efficiency and many others. The investment cycle in the energy sector ranges from several to several dozen years. Predicting is extremely difficult. Its effectiveness depends on many changing, interdependent factors. That is why long-term strategic planning and consistent implementation of the set goals with possible adjustments in response to changing environmental conditions are so important.

In both of the above points, the correlation between the possibilities of energy production and the possibilities of its transmission to the end user is important.

Ad 3 Energy prices are largely an effect of incidental regulatory environment, energy commodity prices on world markets, or operating costs of raw materials in the country, economic downturn / recession of the world economy, natural disasters or technical failures but also the valuation of the rights to $\mathrm{CO}_{2}$ emissions. The effects of the negative impact on the prices of raw materials, which have an impact on the price of electricity, can be minimized by diversifying the directions of supplies and routes of raw material transmission. The independence of raw materials should also be developed, and in the absence of sufficiently rich deposits, domestic production should be maintained at a relatively high level, as a factor stabilizing the prices of energy carriers on the domestic market.

\section{Electricity production}

In February 2021, the Council of Ministers adopted the document Poland's Energy Policy until 2040 (hereinafter PEP2040) determining planned changes in the energy sector. According to the forecasts adopted there, electricity production in Poland will continue to grow over the next two decades. In 2040, it is to reach over 225 terawatt hours (Chart 1). 


\section{Chart No. 1. Production and forecast of electricity production in Poland in 2005 - 2040}

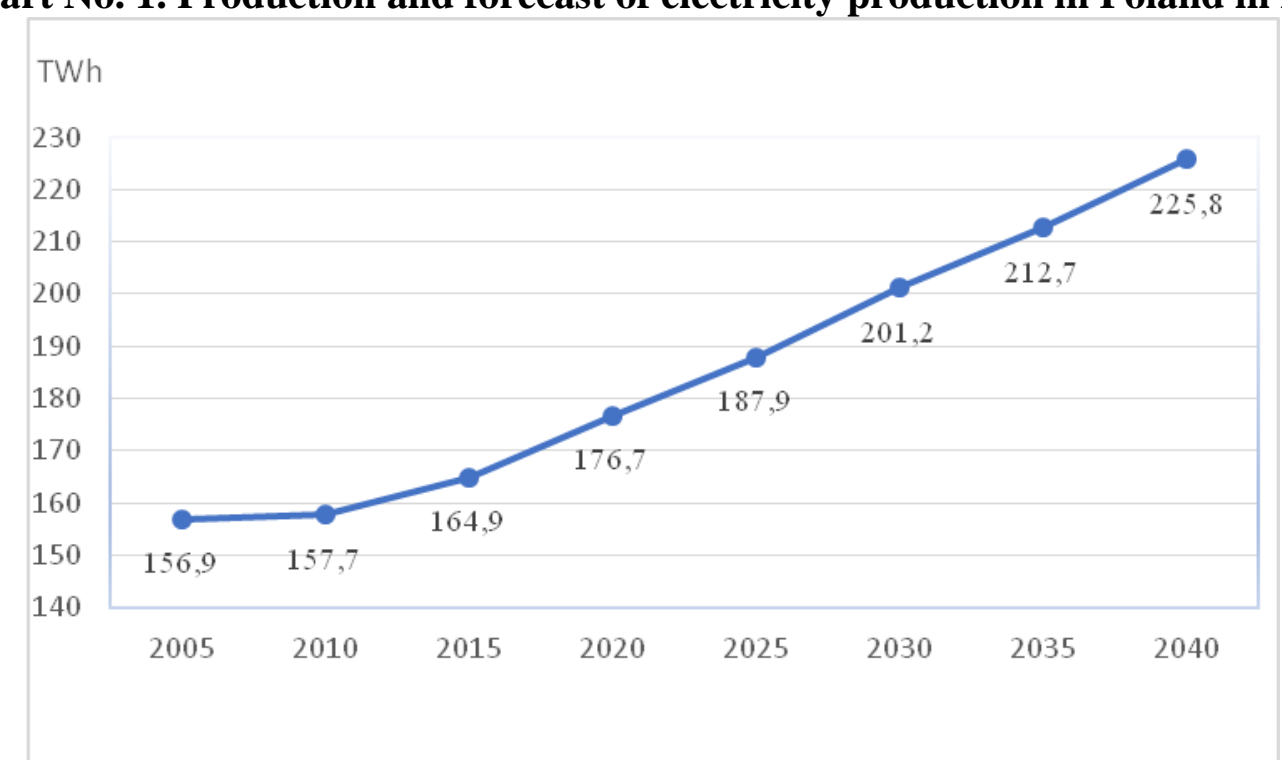

\section{Own study based on: Annex 2 to PEP2040, Conclusions from forecast analyses for the fuel and energy sector.}

If these forecasts are confirmed, it means about $14 \%$ increase in production by 2030 and nearly $28 \%$ increase by 2040 . PEP2040 assumes a relatively high growth of $1.9 \%$ annually. It is likely that the increasing efficiency of energy use and the use of less energy-consuming technologies will result in the increase in electricity demand in the next two decades being lower than assumed in PEP2040.

In recent decades, electricity in Poland was mainly produced by burning black coal and lignite. The share of this raw material in the energy mix is systematically decreasing. In 1990 it was about $90 \%$, in $201680 \%$. In 2020, slightly over $70 \%$ of energy from coal was produced in Poland.

In line with the assumptions of PEP2040, the share of coal in the energy mix will drop to $56 \%$ by 2030 and $28 \%$ in 2040 . Until 2030, this decrease will be compensated by the increase in the share of renewable energy sources to $32 \%$ in 2030 and $40 \%$ in 2040, and from the mid-30s by the connection to the system of the first of the six nuclear power plant units. The role of natural gas will also increase in the power system, in heating and in the household and municipal sector. This will be related to the relatively high flexibility of generation capacities based on this fuel and lower emissions compared to black coal and lignite.

Despite the assumed reduction in the share of coal in the energy mix, the high demand for this raw material will continue. Where will it come from? PEP2040 mainly indicates domestic production, which will mean opening new mines, deepening shafts, and building new or expanding existing mining levels. Black coal mining in Poland, however, has been gradually decreasing from 140 million tonnes in 1995 to 63.4 million tonnes in 2018. The shortage of domestic raw material is supplemented by import, which has almost doubled in recent years from 10.34 million tonnes in 2008 to 19.68 million tonnes in 2018 [TVN24].

The Polish government is working on reforming the coal sector. It will consist in creating a new entity, which will take over coal assets from state-owned companies. They are an increasing burden slowing down the energy transformation. Without freeing oneself from the coal ballast, it will be difficult for energy companies to implement investment programs in renewable energy sources.

In accordance with the assumptions of the restructuring plan, the National Energy Security Agency (hereinafter NABE) will be established, which will take over coal-fired power plants owned by the largest state-owned energy companies: PGE, Enea, Tauron. Only these three entities generated nearly $70 \%$ of electricity in Poland in 2019, the vast majority of which comes from coal. NABE will manage the acquired coal assets until they are completely decommissioned. 
Are the government's plans to restructure the power sector and consolidate coal assets in one entity likely to be implemented? The government seems determined to achieve its goal. Undoubtedly, there is a need for a public debate on the future of the electricity generation sector in Poland, as well as the pace of the transition from coal.

Minister Artur Sobon, responsible for the reform, assumes that NABE will be a commercial project. It will be rather impossible. In the current market environment, the production of energy from coal is less and less profitable, and with the rising prices of $\mathrm{CO}_{2}$ emission allowances, it is conducted with a negative margin. Coal assets depreciate and an additional complication is the division of debts of consolidated companies. Sobon assumes creating a mechanism that will eliminate a possible financial gap and make NABE a profitable project. It seems that the costs of maintaining coal-fired energy will largely fall on the shoulders of taxpayers. It will undoubtedly also reduce the competitiveness of Polish companies.

III. Natural gas as an intermediate fuel

According to the assumptions of PEP2040, in the coming years, the increase in gas consumption on the domestic market will take place through:

1. Construction of gas and steam power units;

2. Stimulating internal demand through deeper gasification of the country. According to the plan of Gaz-System SA, the company responsible for the transport of natural gas and management of the transmission network in Poland, the length of the natural gas transmission network from approx. 12,000 km will now be increased to approx. 14,800 km in 2029 [Gaz-System SA]. The level of gasification in municipalities in Poland will increase from $65 \%$ in 2019 to $77 \%$ already in 2022;

3. Increasing the use of gas in the form of LNG and CNG as an alternative fuel in sea and land transport;

4. It is estimated that reserve generating units will be created for renewable energy sources for which a flexible power reserve is needed. Gas-fired power plants are characterized by a relatively high level of controllability. Although gas is a more expensive fuel than coal, due to the rising prices of emission rights, the final price of energy produced in gas units will be competitive with coal.

Gaz-System SA, in its forecast of the demand for gas transmission services on the domestic market for 2018-2040, developed two variants of the increase in demand: Moderate Growth (UW) and Optimal Growth (OW) (Chart 2). Both variants are based on the signed contracts for connection to the transmission network, GDP growth (UW - assumes low growth of PBK, with the possibility of recession; OW - assumes moderate GDP growth in the absence of recession) and gas prices (UW- assumes price increase due to on the increased demand for the raw material in other EU countries; OW - assumes a moderate increase in the price of gas due to the access to the common market of the European Union and supplies of liquefied gas to Poland) [Gaz-System SA]. 


\section{Chart No. 2. Annual demand for the transmission service based on the forecast of Gaz-System} SA until 2040.

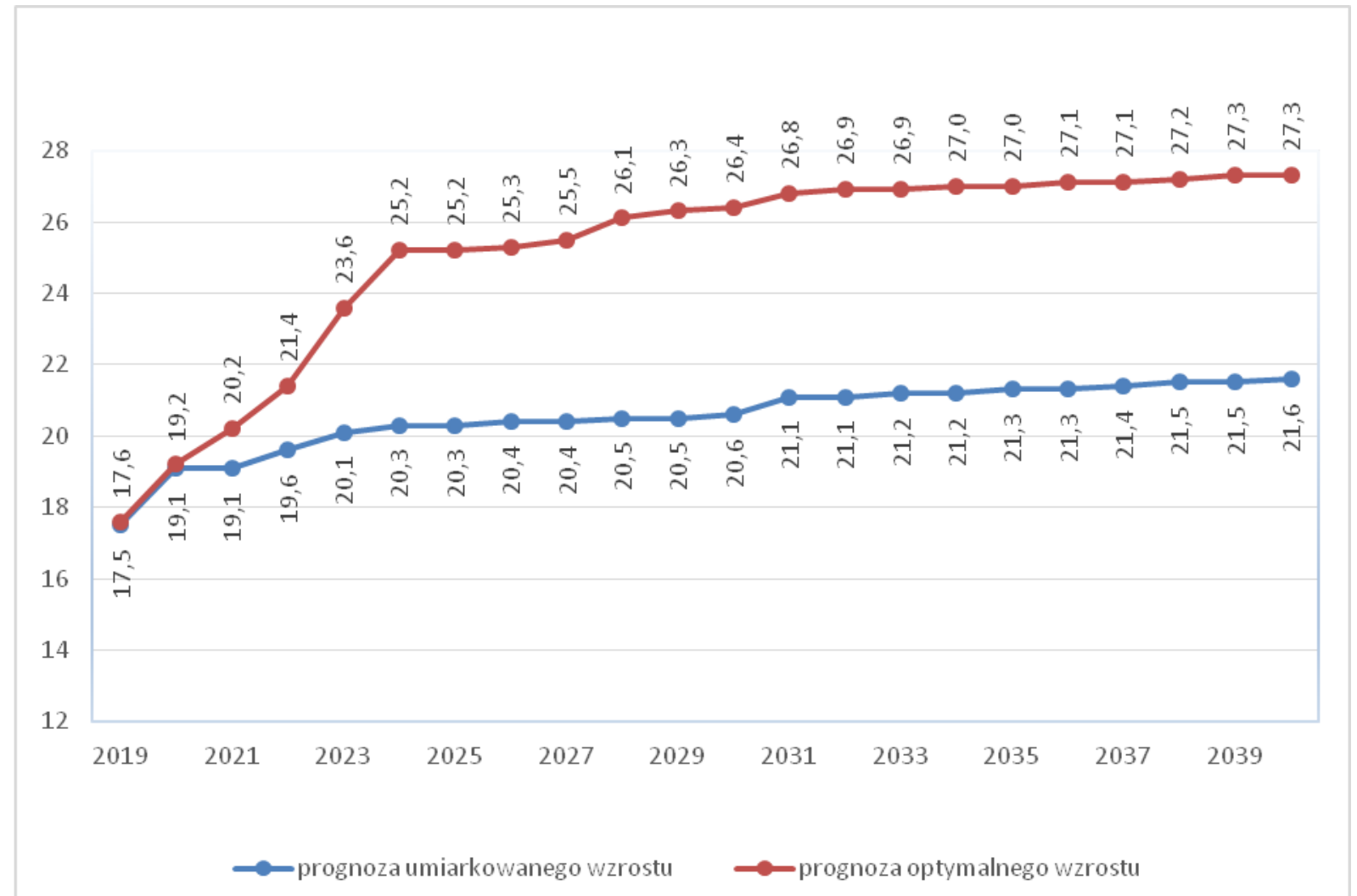

Own study based on: National ten-year transmission system development plan for meeting the current and future demand for gaseous fuels for the years 2020-2029, p. 22

According to the forecasts Gaz System 2030 will record an increase in demand for gas, according to the scenario of 2.6 billion $\mathrm{m}^{3}$ to 8.4 billion $\mathrm{m}^{3}$, mainly in the power industry. Where will we get the additional amount of raw material? PEP2040 emphasizes the development of domestic production, the development of unconventional methods of gas extraction as well as the exploration and exploitation of foreign deposits by domestic entities (especially on the Norwegian Continental Shelf due to the finalization of the Balitc Pipe gas pipeline in 2022). Efforts to increase production and increase the share of domestic raw material in the overall consumption balance will not satisfy the growing demand. Domestic natural gas production in 2040 will remain more or less at the current level [Appendix 1 to PEP2040]. PEP2040 assumes that the increased demand for imported raw material will be covered. In the next decade, however, the structure of the directions of natural gas imports will change. The raw material imported from the east will be replaced with Norwegian gas, LNG from the USA and Qatar. The so-called Yamal contract, under which we import from Russia about 9 billion $\mathrm{m}^{3}$ of gas per year, expires at the end of 2022 [PGNIG 2019]. PEP2040 assumes that by then we will be able to satisfy our basic needs with deliveries from other directions, mainly through:

1. LNG Terminal in Świnoujście. Regasification capacity currently amounts to 5 billion $\mathrm{m}^{3}$ of gas, but by 2021 is to be increased to 7.5 billion $\mathrm{m}^{3}$ per year. The level of use of the gas terminal in 2019 was about $60 \%$. Depending on the development of the global LNG market, there is a possibility to increase the capacity of the terminal to 10 billion $\mathrm{m}^{3}$ until 2030 .

2. Balitc Pipe. According to the plan, the investment should be completed by October 2022. The gas pipeline will transport the raw material from the Norwegian Continental Shelf. Transmission capacity is planned at 10 billion $\mathrm{m}^{3}$ of gas.

3. Construction of the so-called a floating LNG terminal in the Gdańsk Bay until 2025 with regasification capacity at the level of 4.5 billion $\mathrm{m}^{3}$ of gas, which, like the terminal in Świnoujście, will enable diversification of import directions. 
In my opinion, natural gas will play an increasingly important role as a fuel supplying the electricity sector. Data on electricity production in recent years show a clear trend. In 2016, power plants powered by natural gas produced 5.7 TWh of electricity, in $2017-7.1 \mathrm{TWh}$ and in the following year - already $9.5 \mathrm{TWh}$, which accounted for nearly $6 \%$ of the energy generated in the country. According to the assumptions of PEP2040, the capacity of gas power plants in 2040 is to amount to 9.7 thousand. MW (more than in coal and lignite-fired power plants - a total of 8,000 MW), there are also gas-fired CHP plants with a planned capacity in 2040 at the level of 2.74 thousand. MW. We are dealing with a synergy of several factors that will contribute to the implementation of these assumptions. These include: the development of gas supply directions alternative to Russia at a competitive price, market development trends forcing the creation of reserve power plants for RES, development of the transmission system.

\section{Reduction of emissions, nuclear power plant, renewable energy sources}

According to the assumptions of PEP2040, the implementation of nuclear energy is the only way to satisfy energy shortages after excluding some of the ineffective carbon sources and to reduce gas emissions (i.e. carbon dioxide $\mathrm{CO}_{2}$, nitrogen oxides $\mathrm{NO}_{\mathrm{x}}$, sulfur oxides $\mathrm{SO}_{\mathrm{x}}$ ) and dust. The first unit with a capacity of 1-1.5 GW should be commissioned in 2033, the next 5 units, with a similar capacity, at intervals of 2-3 years. Are these plans real? The Polish authorities have been working on the implementation of nuclear energy for over 10 years, the effects of these efforts are not satisfactory. In January 2009, the Council of Ministers adopted a resolution on the development of nuclear energy [Resolution of the Council of Ministers 2009] . In May of the same year, pursuant to the resolution, the Government Plenipotentiary for Polish Nuclear Power was appointed (Journal Of Laws of 2009, No. 72, item 622), and in 2014 the Council of Ministers adopted the Polish Nuclear Power Program [Resolution of the Council of Ministers, 2014]. Polska Grupa Energetyczna (PGE) SA, as a leading entity in the construction of nuclear energy in Poland, established the special purpose company PGE EJ1 in 2010, whose direct task is to prepare and implement the investment process for the construction of the first Polish nuclear power plant. In March 2018, the Supreme Audit Office published a report on the implementation of the Polish Nuclear Energy Program (PPEJ). The Supreme Audit Office stated that the essential tasks set out in the PPEJ were not implemented, deemed the planned commissioning of the first unit in 2024 unrealistic, criticized the changes in the concept of building a nuclear power plant and the low effectiveness of the activities of the relevant ministers. According to the NIK Report, PGE EJ1 spent PLN 133.2 million in the years 2010-2014, i.e. in the preparatory period before adopting PPEJ. In 2014-2017 (until the third quarter), the expenditure amounted to PLN 776 million (including PLN 552.5 million by public administration entities and PLN 223 million by PGE SA and its subsidiary) [NIK 2017]. According to the NIK auditors, the main reason for the delay in the implementation of PPEJ for several years was the lack of choice of technology and contractor for the construction of a nuclear power plant. Although nearly three years have passed since the publication of the NIK report, little has changed in this respect. The government is in talks with technology vendors, but no decisions have been made. We also do not know the location of the future power plant. PEP2040 indicates three potential locations: Kopalino in the Choczewo commune, Żarnowiec in the Krokowa commune in Pomerania or the vicinity of Bełchatów or Pątnów. The first two towns have been taken into account for a long time and PGE EJ1 implemented the location and environmental tasks provided for by the PPEJ, and the attitude of the local community towards the construction of power plants in their municipalities is favorable [Partner in Business Strategies 2018] . The Supreme Audit Office estimates that the delay in starting a nuclear power plant will generate specific costs related to the need to purchase emission rights, estimated at PLN 253-430 million annually in 2025-2030 [NIK 2017] .

The Polish Energy Policy until 2030, adopted in 2009, set the commissioning of the first block of a nuclear power plant for 2020. This clearly illustrates the planning errors, lack of decision 
and lack of consistency in action by all governments in power over the past decade. The situation in terms of the condition of the Polish economy and public support for the nuclear power plant was exceptionally favorable for the development of nuclear energy. Currently, the Polish authorities are negotiating with three potential technology suppliers - the US, Japan and France, but unfortunately without any specific decisions. If the assumptions of PEP2040 in the field of nuclear energy are to be implemented in the form of the first reactor put into operation in 2033, a model for financing the investment (in line with the rules of state aid), the choice of technology and location should be established in the next several months. Taking into account the pace of the implementation of the PNPP so far, it seems unlikely in my opinion.

The share of Renewable Energy Sources (hereinafter RES) in the final energy consumption does not develop dynamically. Pursuant to Directive 2009/28 / EC of the European Parliament and of the Council of the European Union, Poland was obliged to produce at least $15 \%$ of final energy by 2020 from renewable sources. At the beginning of 2019, the Polish government, in the National Energy and Climate Plan for 2021-2030 sent to the European Commission (draft) [National energy and climate plan], admitted that the $15 \%$ share of renewable energy in the final consumption will not be achieved in 2020. The plan is to reach this level only in 2022. PEP2040 assumes an increase in the share of renewable energy sources in gross final energy consumption at a level of at least $23 \%$ by 2030 . In the electricity sector, the share of RES will be at the higher levels of $32 \%$ in 2030 and $40 \%$ in 2040. Increasing the share of renewable energy sources entails a lot of benefits for the Polish electricity and energy sector, such as, for example, diversification of the local generation infrastructure, zero emissions or limiting the import of fossil fuels. However, a question should be asked whether the assumptions of PEP2040 regarding the share of RES in final energy consumption are realistic? In the 2010-2020 decade, we increased the share of renewable energy sources in final energy consumption by only $4.55 \%$ from $9.25 \%$ to $13.8 \%$ and we did not achieve the assumed goals. In the 2020-2030 decade, the government assumes that the growth dynamics will more than double, i.e. by nearly $10 \%$ (from $13.8 \%$ in 2020 to $23 \%$ in 2030).

\section{Conclusions}

PEP2040 is conservative in many respects. It sets unambitious goals for reducing $\mathrm{CO}_{2}$ emissions, a low growth rate of renewable energy sources in the power sector and a slow process of phasing out coal in energy production. This raises serious concerns about the failure of the power system, an accelerated process of closing coal-fired power plants due to non-compliance with emission standards, and the depletion of lignite deposits faster than assumed in PEP2040. If the process of reducing the generation capacity of lignite-fired power plants is not carried out in parallel with the development of nuclear energy, we can expect a shortage of electricity of up to $9 \mathrm{GW}$ [Gawlikowska-Fyk A., Maćkowiak-Pandera J., (2019)] . The government does not take real steps to launch the first nuclear power plant by 2033. Meeting the assumptions of PEP2040 in this respect seems unlikely. This may result in the necessity to extend the operation of some coal units which are planned to be decommissioned, and thus the high costs of energy generation, negatively affecting the competitiveness of the entire economy. There is also the risk of having to increase energy imports from our neighbours. The mock "construction" of a nuclear power plant may also block the development of other sectors, e.g. offshore wind farms, due to the limitations of the transmission grid.

It seems, however, that the market will force, regardless of government actions, the acceleration of certain processes. The constantly developing technologies of energy production from RES that affect the decline in prices, combined with the popularization of use, will probably cause a faster growth rate of the share of RES than assumed in PEP 2040. PPAs - Corporate Power Purchase Agreements concluded between energy producers and recipients, regardless of stateowned producers, have gained in attractiveness. 


\section{References}

1. Bronk L., Czarnecki B.,. Magulski R, (2019) Flexibility of the National Power System. Diagnosis, potential, solutions, "Forum Energii", February 2019, p. 19.

2. "Poland's Energy Policy until 2030", Annexes to Resolution No. 202/2009 of the Council of Ministers of November 10, 2009, Ministry of Economy, p. 8.

3. "Poland's Energy Policy until 2040" project in. 2.1 - 08/11/2019), p. 10.

4. TVN24, https://tvn24bis.pl/surowce,78/import-wegla-do-polski-minister-srodowiskahenryk-kowalczyk-wyjasnia,968651.html,

5. Gaz-System SA, National ten-year transmission system development plan for meeting the current and future demand for gaseous fuels for the years 2020 - 2029, p. 30.

6. Gaz-System SA, National ten-year transmission system development plan for meeting the current and future demand for gaseous fuels for the years 2020 - 2029, p. 19.

7. See Appendix 1 to PEP2040, Conclusions from forecast analyses for the fuel and energy sector, p. 12.

8. PGNIG - On November 15, 2019, Polskie Górnictwo Naftowe i Gazownictwo issued a declaration of the lack of will to extend the so-called Jamal contract http://pgnig.pl/aktualnosci/-/news-list/id/oskieta-woli-zakonczenia-kontraktu-jamalskiego-zdniem-31-grudnia-2022-roku/newsGroupId/10184? changeYear=2019 $\propto$ tPage $=3$ (accessed on January 3, 2020).

9. Resolution of the Council of Ministers of 13 January 2009 (No. 4/2009) on activities undertaken for the development of nuclear energy in Poland.

10. Resolution of the Council of Ministers of 28 January 2014 (No. 15/2014) on the multiannual program called the Polish Nuclear Power Program (MP of 2014, item 502)

11. NIK information on the audit results: Implementation of the "Polish Nuclear Power Program", reg. No. 169/2017 / P / 17/018 / KGP, p. 10.

12. Partner in Business Strategies, Poles' attitudes towards nuclear energy, Research report, Sopot, December 2018.

13. NIK information on the audit results: Implementation of the "Polish Nuclear Power Program", reg. No. 169/2017 / P / 17/018 / KGP, pp. 31-32.

14. National energy and climate plan for 2021-2030. Assumptions and goals as well as policies and activities, PROJECT - in. 3.1 of 04/01/2019, the text is available on the website of the Ministry of State Assets https://www.gov.pl/web/aktywa-panstwowe .

15. Gawlikowska-Fyk A., Maćkowiak-Pandera J., (2019) PEP2040 under the magnifying glass of Forum Energii. Comments and recommendations to the draft Polish Energy Policy until 2040, Forum Energii, Warsaw 2019, https://www.forum-energii.eu/pl/analizy/pep-2040uwagi 